\title{
Electrospray Mass Spectrometry and Tandem Mass Spectrometry of Bimetallic Oxovanadium Complexes
}

\author{
Zhi-Jun $\mathrm{Wu}$, ${ }^{\mathrm{a}, \mathrm{d}}$ Xiao-Ying $\mathrm{Xu}^{\mathrm{b}}{ }^{\mathrm{b}}$ Shi-Wei Luo, ${ }^{\mathrm{c}}$ \\ Dong-Mei Fang, ${ }^{a}$ and Guo-Lin Zhang ${ }^{a}$ \\ ${ }^{a}$ Chengdu Institute of Biology, Chinese Academy of Sciences, Chengdu, China \\ ${ }^{b}$ Key Laboratory of Asymmetric Synthesis and Chirotechnology of Sichuan Province and Union Laboratory \\ of Asymmetric Synthesis, Chengdu Institute of Organic Chemistry, Chinese Academy of Sciences, Chengdu, \\ China \\ ${ }^{c}$ Department of Chemistry, University of Science and Technology of China, Hefei, China \\ ${ }^{\mathrm{d}}$ Graduate School of Chinese Academy of Sciences, Beijing, China
}

\begin{abstract}
A series of six bimetallic oxovanadium complexes (1-6; only one was purified) were investigated by electrospray quadrupole time-of-flight tandem mass spectrometry (ESI-QTOFMS/MS) in negative-ion mode. Radical molecular anions $[\mathrm{M}]^{-}$were observed in MS mode. Fragmentation patterns of $[\mathrm{M}]^{-}$were proposed, and elemental compositions of most of the product ions were confirmed on the basis of the high-resolution ESI-CID-MS/MS spectra. A complicated series of low-abundance product ions similar to electron impact (EI) ionization spectra indicated the radical character of the precursor ions. Fragment ions at $m / z 214,200$, and 182 seem to be the characteristic ions of bimetallic oxovanadium complexes. These ions implied the presence of a $\mathrm{V}-\mathrm{O}-\mathrm{V}$ bridge bond, which might contribute to stabilization of the radical. To obtain more information for structural elucidation, three representative bimetallic oxovanadium complexes (1-3) were analyzed further by MS in positive-ion mode. Positive-ion ESI-MS produced adduct ions of $\left[\mathrm{M}+\mathrm{H}^{+},[\mathrm{M}+\mathrm{Na}]^{+}\right.$, and $[\mathrm{M}+\mathrm{K}]^{+}$. The fragmentation patterns of $[\mathrm{M}+\mathrm{Na}]^{+}$were different than those of radical molecular anions $\left[\mathrm{M}^{-}\right.$. Relatively simple fragmentation occurred for $\left[\mathrm{M}+\mathrm{Na}^{+}\right.$, possibly due to even-electron ion character. Negative-ion MS and MS/MS spectra of the hydrolysis product of Complex 1 supported these finding, in particular, the existence of a V-O-V bridge bond. (J Am Soc Mass Spectrom 2008, 19, 1247-1254) $\odot 2008$ American Society for Mass Spectrometry
\end{abstract}

$\mathrm{O}$ xovanadium complexes have played active roles in the fields of pharmaceutical research and organic synthesis. These complexes exhibit attractive promise as orally available treatments for diabetes mellitus and also have a number of applications as catalysts in various oxidation reactions [1-10]. Recently, some oxovanadium complexes, especially bimetallic oxovanadium complexes of chiral Schiff bases reported by Gong's group, were shown to provide high enantioselectivity for the oxidative coupling of 2-naphthols, which play very important roles in the history of asymmetric synthesis [11-17].

Structural characterization of the bimetallic oxovanadium complexes is key to the further development of their functions. Nuclear magnetic resonance (NMR) spectroscopy $\left({ }^{1} \mathrm{H}\right.$ and $\left.{ }^{51} \mathrm{~V}\right)$ can provide abundant information for structural analyses of bimetallic oxovanadium complexes. Unfortunately, NMR measurements

Address reprint requests to Dr. Z.-J. Wu, Chengdu Institute of Biology, Chinese Academy of Sciences, Chengdu 610041, China. E-mail: wuzhijunyinger@ 163.com require pure samples, which are difficult to obtain for most bimetallic oxovanadium complexes [17]. X-ray crystallographic analyses require the production of monocrystals, which limits the applicability of this technique for structural characterization. Furthermore, UV, IR, and ESR spectroscopy offer only limited structural information [18]. Obviously, a method that provides abundant structural information without laborious purification would be highly desirable for the structural characterization of the bimetallic oxovanadium complexes.

Mass spectrometry (MS) has greatly benefited from the development of electrospray ionization (ESI) and has been applied successfully in various fields. A series of simple oxovanadium complexes has been studied by ESI-MS [19-24]. Recently, Zeng et al. reported the fragmentation study of monometallic oxovanadium Schiff base complexes by ESI-IT-MS ${ }^{n}$ [25]. However, it seems not to obtain the information of uniform fragmentation patterns, except for the loss of $\mathrm{CO}_{2}$. Surprisingly, in our recent work, the $[\mathrm{M}]^{-}$ radical ions of bimetallic oxovanadium complexes were observed for the first time in negative-ion mode, 


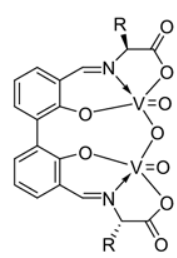

1, $\mathrm{R}=\mathrm{CH}_{3} \mathrm{CHCH}_{2} \mathrm{CH}_{3}$ $\left(\mathrm{C}_{26} \mathrm{H}_{28} \mathrm{O}_{9} \mathrm{~N}_{2} \mathrm{~V}_{2}, \mathrm{Mr}_{r} 614.0674\right)$

2, $\mathrm{R}=4-\mathrm{MeOC}_{6} \mathrm{H}_{4} \mathrm{CH}_{2}$

$\left(\mathrm{C}_{34} \mathrm{H}_{28} \mathrm{O}_{11} \mathrm{~N}_{2} \mathrm{~V}_{2}, M_{r} 742.0572\right.$

Figure 1. Structures of bimetallic oxovanadium Complexes 1-6.

which provided important proof for a radical-based mechanism [17].

To obtain sufficient fragmentation information for the structural elucidation of more bimetallic oxovanadium complexes, and to understand the radical behavior in the gas phase during the CID MS/MS experiments with potential extension to insight into the radical-based reaction mechanism, the ionization and fragmentation of six ionic bimetallic oxovanadium complexes of chiral Schiff bases were studied by electrospray ionization quadrupole time-of-flight mass spectrometry (ESI-QTOF) in negative-ion mode (three complexes were also studied in positive-ion mode). Characteristic fragment ions and uniform fragmentation patterns were elucidated.

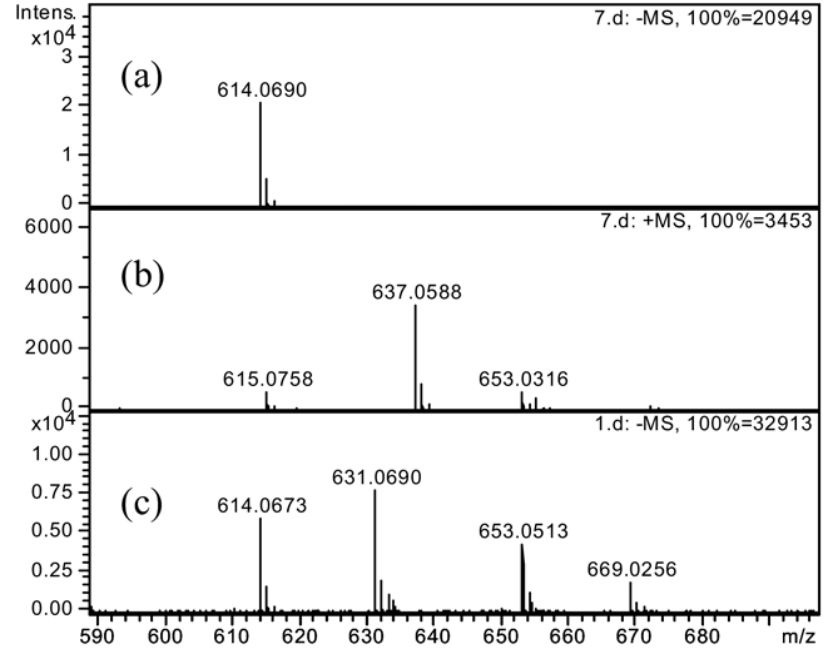

Figure 2. MS spectra of oxovanadium Complex 1 and the hydrolysis product of $\mathbf{1}$. (a) Complex $\mathbf{1}$ in negative-ion mode ([M] ${ }^{-}$at $m / z$ 614). (b) Complex $\mathbf{1}$ in positive-ion mode ([M + $\mathrm{H}]^{+}$at $m / z 615,[\mathrm{M}+\mathrm{Na}]+$ at $m / z 637,[\mathrm{M}+\mathrm{K}]^{+}$at $\left.m / z 653\right) .(\mathbf{c})$ Hydrolysis product of $\mathbf{1}$ in negative-ion mode $\left([\mathrm{M}+\mathrm{H} 2 \mathrm{O}-\mathrm{H}]^{-}\right.$ at $m / z$ 631, [M $+\mathrm{H} 2 \mathrm{O}-2 \mathrm{H}+\mathrm{Na}]^{-}$at $m / z$ 653, [M $+\mathrm{H} 2 \mathrm{O}-$ $2 \mathrm{H}+\mathrm{K}]^{-}$at $\left.m / z 669\right)$.

\section{Experimental}

\section{Chemicals and Samples}

HPLC-grade acetonitrile was purchased from Fisher Scientific (Pittsburgh, PA), thrice-deionized water from

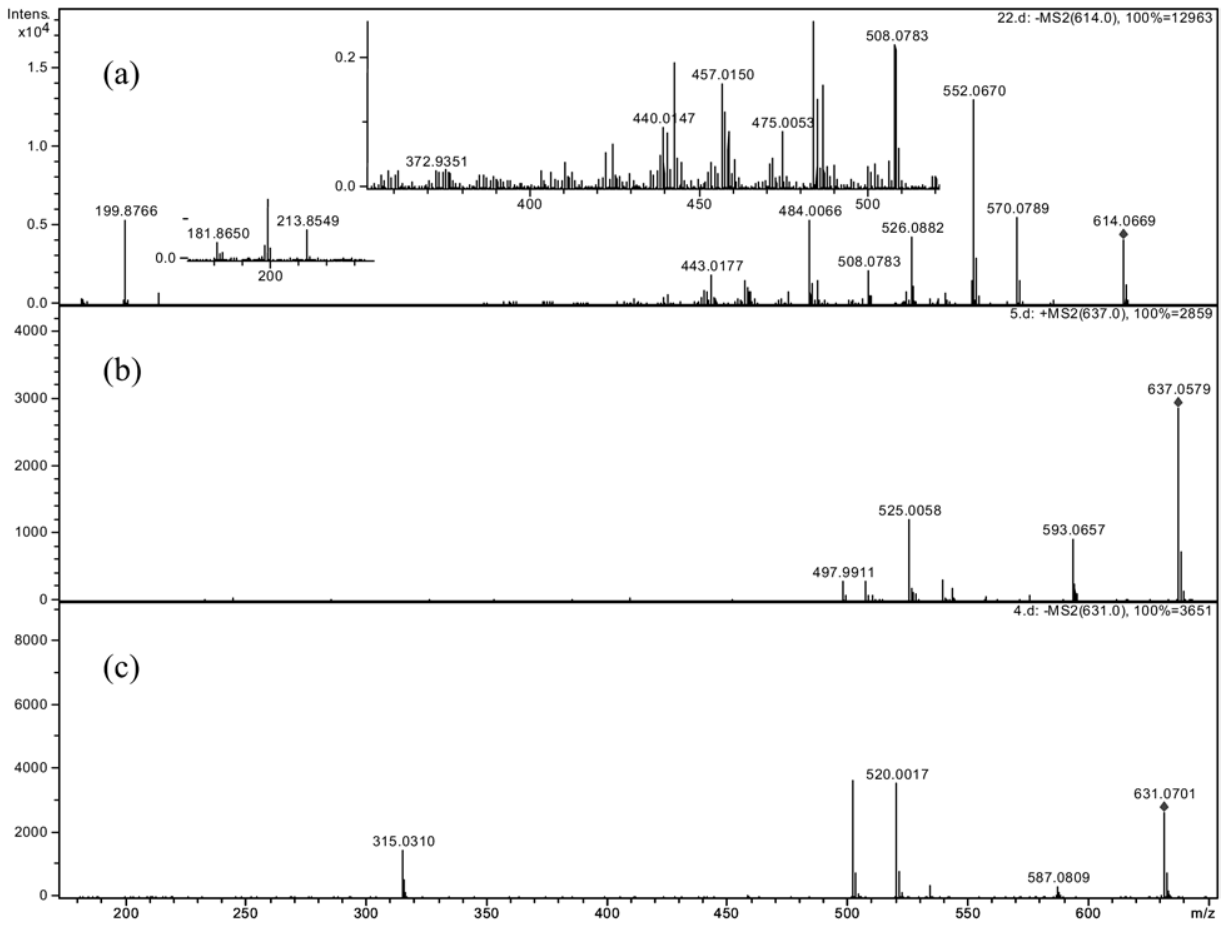

Figure 3. MS/MS spectra of oxovanadium Complex 1 and hydrolysis product of $\mathbf{1}$ : (a) selected [M] ${ }^{-}$ at $m / z 614$ (collision energy at $35 \mathrm{eV}$ ), (b) selected [M $+\mathrm{Na}]^{+}$at $\mathrm{m} / z 637$ (collision energy at $20 \mathrm{eV}$ ), and (c) selected $[\mathrm{M}+\mathrm{H} 2 \mathrm{O}-\mathrm{H}]^{-}$at $\mathrm{m} / \mathrm{z} 631$ (collision energy at $10 \mathrm{eV}$ ). 
HaiHong (Chengdu, China), and methanol mass calibration standards from Agilent Technologies (Palo Alto, CA). AR-grade chloroform from Bodi Corp. (Tianjin, China) was used for dissolution of samples, which were then diluted with acetonitrile before introduction to the mass spectrometer. The bimetallic oxovanadium complexes were synthesized in Gong's laboratory. Only Complex 1 was purified and its structure was confirmed by ${ }^{1} \mathrm{H},{ }^{13} \mathrm{C}$, and ${ }^{51} \mathrm{~V}$ NMR spectra. A pure sample was difficult to achieve for the other complexes. The structures of Complexes 1-6 are shown in Figure 1. Oxovanadium Complexes 1, 2 were prepared by condensation of 3,3'-diformyl-2,2'-dihydroxy-2-phenol with (S)-amino acids and vanadyl sulfate. Complexes 3-6 are $\mathrm{H}_{8}$-BINOL-based bimetallic chiral oxovanadium complexes.

\section{Instrument}

High-resolution experiments were performed on a Bruker BioTOF-Q mass spectrometer (Billerica, MA) in both positive and negative modes. Accurate masses of fragment ions were determined by external mass calibration using the mass calibrants of MW 622.0290 and 922.0098 in the positive mode and of MW 431.9823, 601.9790 and 1033.9870 in the negative mode. Another injector was used to introduce the mass calibrants into MS, shortly after introducing the samples. High-purity nitrogen gas at a pressure of 30 psi was used as collision, nebulizer, and auxiliary heated gas. The samples introduction rate was $115 \mu \mathrm{L} / \mathrm{h}$. The ESI source conditions in the positive and negative modes were as follows: capillary V, $-4500 \mathrm{~V}$ (positive), $4000 \mathrm{~V}$ (negative); end plate voltage, $-4000 \mathrm{~V}$ (positive), $3500 \mathrm{~V}$ (negative); capillary exit voltage, $120 \mathrm{~V}$; and the dry gas temperature, $150{ }^{\circ} \mathrm{C}$. The collision energy was optimized according to the signal.

\section{Results and Discussion}

\section{$M S$ and $M S / M S$ of Complex $\mathbf{1}$}

The MS and MS/MS experiments for Complex 1 were performed in both positive- and negative-ion modes. The radical molecular anions $[\mathrm{M}]^{--}$at $\mathrm{m} / \mathrm{z}$ 614 were detected in negative-ion mode with strong absolute abundance (Figure 2a). The fragmentation of $m / z 614$ yielded fragment-rich product ions (Figure 3a). The major fragmentation patterns are shown in Scheme 1. The loss of a $\mathrm{CO}_{2}$ molecule from Complex 1 occurs readily. The loss of an $\mathrm{H}_{2} \mathrm{O}$ molecule possibly involves two intermediates that also play substantial roles in the production of other fragment ions. Intermediate I is likely formed by hexagonal hydrogen rearrangement and further produces intermediate II by a retro-1,1-insertion reaction. The fragmentation of the amino acids part of Complex 1 was complicated, and a series of lowabundance peaks similar to the electron impact (EI) ionization spectrum were observed. The series of peaks likely indicates the radical character of the precursor ion $[\mathrm{M}]^{--}$at $m / z 614$.

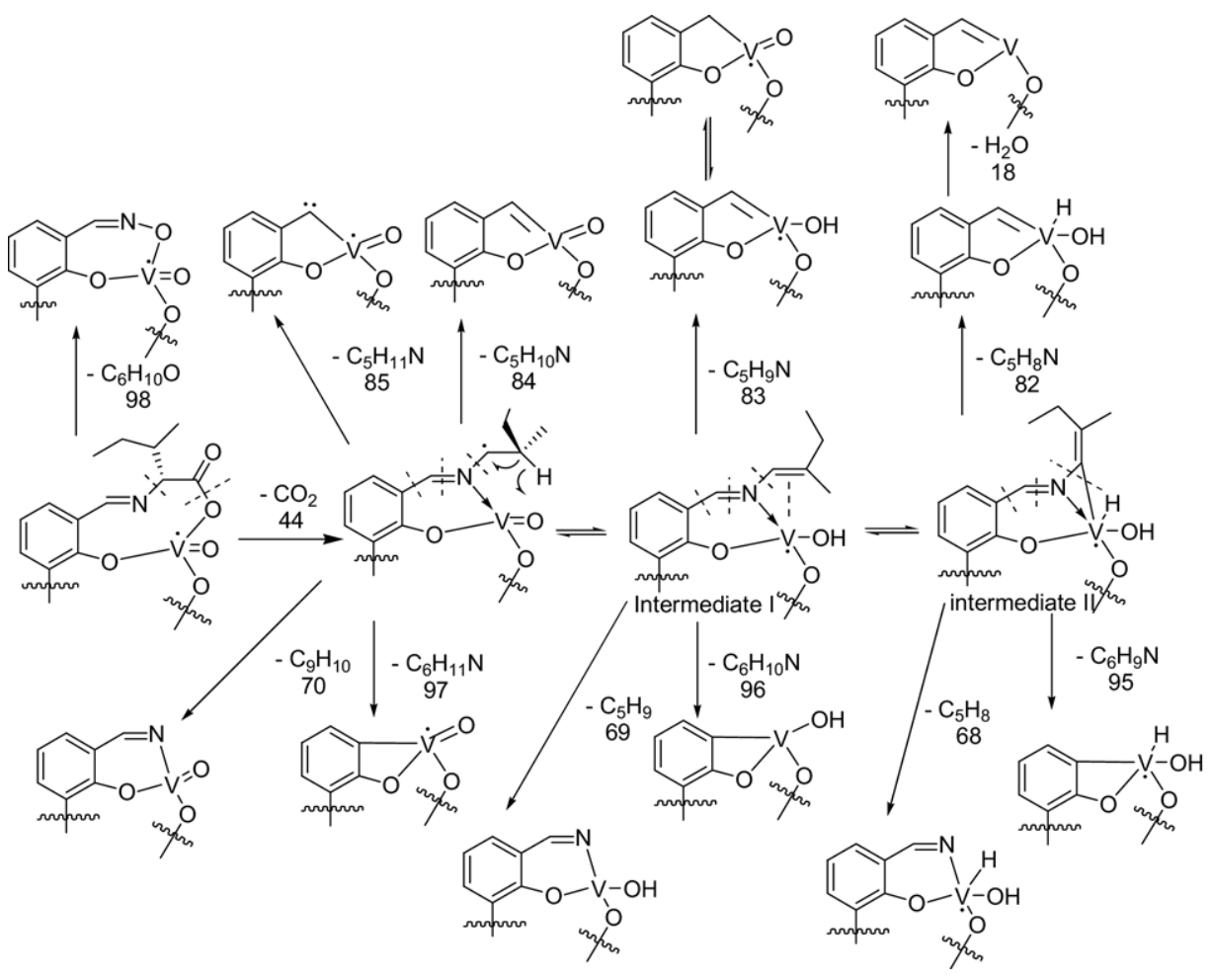

Scheme 1. Major neutral losses from oxovanadium Complex 1. 


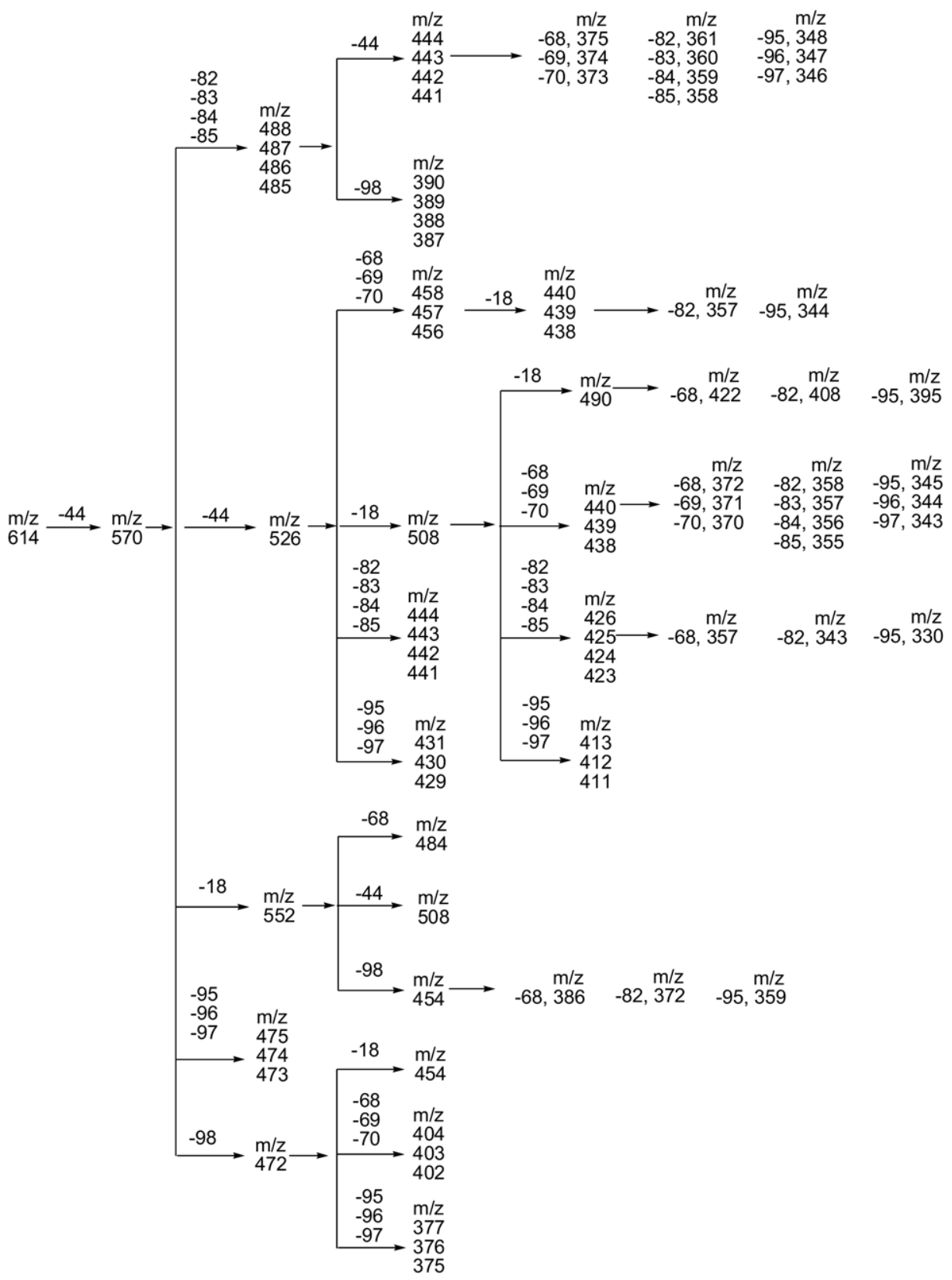

Scheme 2. Possible fragmentation pathways of the selected $[\mathrm{M}]^{--}$at $\mathrm{m} / \mathrm{z} 614$ for oxovanadium Complex 1. Pathways were postulated from ESI-QTOF-MS/MS spectra.

Detailed fragmentation pathways of the precursor ion $[\mathrm{M}]^{-}$at $\mathrm{m} / \mathrm{z} 614$ were postulated on the basis of high-resolution MS/MS spectra (Scheme 2). By combining Schemes 1 and 2, the processes for the formation of most product ions could be elucidated. The exact masses of major fragment ions supported this analysis (Table 1). Notably, the low-mass fragment ions at $\mathrm{m} / \mathrm{z}$ 214, 200, and 182 appeared to be the characteristic ions, and their possible elemental compositions correspond to $\mathrm{V}_{2} \mathrm{O}_{7}, \mathrm{C}_{3} \mathrm{NV}_{2} \mathrm{O}_{3}$, and $\mathrm{V}_{2} \mathrm{O}_{5}$, respectively. These ions, including the structure of $\mathrm{V}-\mathrm{O}-\mathrm{V}$ bridge, implied the presence of a $\mathrm{V}-\mathrm{O}-\mathrm{V}$ bridge bond. The radical molecu- lar ions $[\mathrm{M}]^{--}$were not observed for monometallic oxovanadium complexes [25], so the $\mathrm{V}-\mathrm{O}-\mathrm{V}$ bridge bond might contribute substantially to the stabilization of the radical. Incidentally, the fragment ions of $\mathrm{m} / \mathrm{z} 614$ with high relative abundance were odd-electron ions, except for $m / z 200$ (Table 1).

Positive-ion ESI-MS revealed adduct ions of [M + $\mathrm{H}]^{+}$at $m / z 615,[\mathrm{M}+\mathrm{Na}]^{+}$at $m / z 637$, and $[\mathrm{M}+\mathrm{K}]^{+}$ at $m / z 653$ (Figure $2 b$ ). In the MS/MS spectrum of the precursor ion $[\mathrm{M}+\mathrm{Na}]^{+}$at $m / z 637$, neither a series of low-abundance peaks similar to the EI spectrum nor low-mass characteristic ions were observed 
Table 1. Major fragment ions from oxovanadium complex $\mathbf{1}$ in negative-ion mode and their elemental constituents (collision energy at $35 \mathrm{eV}$ )

\begin{tabular}{|c|c|c|c|c|}
\hline Fragment ions & Formula & Calculated & Observed & Error (ppm) \\
\hline$\overline{[\mathrm{M}]^{--}}$ & $\mathrm{C}_{26} \mathrm{H}_{28} \mathrm{O}_{9} \mathrm{~N}_{2} \mathrm{~V}_{2}$ & 614.0680 & 614.0669 & +1.78 \\
\hline$[\mathrm{M}-44]^{--}$ & $\mathrm{C}_{25} \mathrm{H}_{28} \mathrm{O}_{7} \mathrm{~N}_{2} \mathrm{~V}_{2}$ & 570.0781 & 570.0789 & -1.29 \\
\hline$[\mathrm{M}-44-18]^{--}$ & $\mathrm{C}_{25} \mathrm{H}_{26} \mathrm{O}_{6} \mathrm{~N}_{2} \mathrm{~V}_{2}$ & 552.0676 & 552.0670 & +0.97 \\
\hline$[\mathrm{M}-44-44]^{--}$ & $\mathrm{C}_{24} \mathrm{H}_{28} \mathrm{O}_{5} \mathrm{~N}_{2} \mathrm{~V}_{2}$ & 526.0883 & 526.0882 & +0.14 \\
\hline$[\mathrm{M}-44-44-18]^{--}$ & $\mathrm{C}_{24} \mathrm{H}_{26} \mathrm{O}_{4} \mathrm{~N}_{2} \mathrm{~V}_{2}$ & 508.0777 & 508.0783 & -1.05 \\
\hline$[\mathrm{M}-44-83]^{--}$ & $\mathrm{C}_{20} \mathrm{H}_{19} \mathrm{O}_{7} \mathrm{NV}_{2}$ & 487.0046 & 487.0049 & -0.62 \\
\hline$[\mathrm{M}-44-18-68]^{--}$ & $\mathrm{C}_{20} \mathrm{H}_{18} \mathrm{O}_{6} \mathrm{~N}_{2} \mathrm{~V}_{2}$ & 484.0050 & 484.0066 & -3.49 \\
\hline$[\mathrm{M}-44-95]^{--}$ & $\mathrm{C}_{19} \mathrm{H}_{19} \mathrm{O}_{7} \mathrm{NV}_{2}$ & 475.0046 & 475.0053 & -1.32 \\
\hline$[\mathrm{M}-44-98]^{--}$ & $\mathrm{C}_{19} \mathrm{H}_{18} \mathrm{O}_{6} \mathrm{~N}_{2} \mathrm{~V}_{2}$ & 472.0050 & 472.0062 & -2.70 \\
\hline$[\mathrm{M}-44-44-69]^{-}$ & $\mathrm{C}_{19} \mathrm{H}_{19} \mathrm{O}_{5} \mathrm{~N}_{2} \mathrm{~V}_{2}$ & 457.0179 & 457.0150 & +6.20 \\
\hline$[\mathrm{M}-44-98-18]^{--}$ & $\mathrm{C}_{19} \mathrm{H}_{16} \mathrm{O}_{5} \mathrm{~N}_{2} \mathrm{~V}_{2}$ & 453.9944 & 453.9942 & +0.45 \\
\hline 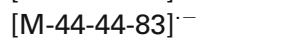 & $\mathrm{C}_{19} \mathrm{H}_{19} \mathrm{O}_{5} \mathrm{NV}_{2}$ & 443.0148 & 443.0177 & -6.46 \\
\hline$[\mathrm{M}-44-44-18-68]^{--}$ & $\mathrm{C}_{19} \mathrm{H}_{18} \mathrm{O}_{4} \mathrm{~N}_{2} \mathrm{~V}_{2}$ & 440.0151 & 440.0147 & +1.01 \\
\hline$[\mathrm{M}-44-44-18-83]^{--}$ & $\mathrm{C}_{19} \mathrm{H}_{17} \mathrm{O}_{4} \mathrm{NV}_{2}$ & 425.0042 & 425.0035 & +1.64 \\
\hline$[\mathrm{M}-44-44-18-85]^{--}$ & $\mathrm{C}_{19} \mathrm{H}_{15} \mathrm{O}_{4} \mathrm{NV}_{2}$ & 422.9886 & 422.9898 & -2.87 \\
\hline$[\mathrm{M}-44-44-18-95]^{--}$ & $\mathrm{C}_{18} \mathrm{H}_{17} \mathrm{O}_{4} \mathrm{NV}_{2}$ & 413.0042 & 413.0016 & +6.26 \\
\hline$[\mathrm{M}-44-44-18-97]^{--}$ & $\mathrm{C}_{18} \mathrm{H}_{15} \mathrm{O}_{4} \mathrm{NV}_{2}$ & 410.9886 & 410.9886 & -0.02 \\
\hline$[\mathrm{M}-44-44-18-83-18]^{--}$ & $\mathrm{C}_{19} \mathrm{H}_{15} \mathrm{O}_{3} \mathrm{NV}_{2}$ & 406.9937 & 406.9929 & +1.88 \\
\hline$[\mathrm{M}-44-98-68]^{-}$ & $\mathrm{C}_{14} \mathrm{H}_{10} \mathrm{O}_{6} \mathrm{~N}_{2} \mathrm{~V}_{2}$ & 403.9424 & 403.9427 & -0.92 \\
\hline$[\mathrm{M}-44-44-69-84]^{\cdot-}$ & $\mathrm{C}_{14} \mathrm{H}_{9} \mathrm{O}_{5} \mathrm{NV}_{2}$ & 372.9365 & 372.9351 & +3.97 \\
\hline$\left[\mathrm{V}_{2} \mathrm{O}_{7}\right]^{--}$ & $\mathrm{V}_{2} \mathrm{O}_{7}$ & 213.8529 & 213.8549 & -9.40 \\
\hline$\left[\mathrm{C}_{3} \mathrm{NV}_{2} \mathrm{O}_{3}\right]^{-}$ & $\mathrm{C}_{3} \mathrm{NV}_{2} \mathrm{O}_{3}$ & 199.8763 & 199.8766 & -1.53 \\
\hline$\left[\mathrm{V}_{2} \mathrm{O}_{5}\right]^{--}$ & $\mathrm{V}_{2} \mathrm{O}_{5}$ & 181.8630 & 181.8650 & -10.5 \\
\hline
\end{tabular}

Table 2. Major fragment ions from oxovanadium complex 1 in positive-ion mode and their elemental constituents (collision energy at $20 \mathrm{eV}$ )

\begin{tabular}{llccc}
\hline \multicolumn{1}{c}{ Fragment ions } & Formula & Calculated & Observed & Error (ppm) \\
\hline \hline$[\mathrm{M}+\mathrm{Na}]^{+}$ & $\mathrm{C}_{26} \mathrm{H}_{28} \mathrm{O}_{9} \mathrm{~N}_{2} \mathrm{~V}_{2} \mathrm{Na}$ & 637.0566 & 637.0579 & -2.06 \\
{$[\mathrm{M}+\mathrm{Na}-44]^{+}$} & $\mathrm{C}_{25} \mathrm{H}_{28} \mathrm{O}_{7} \mathrm{~N}_{2} \mathrm{~V}_{2} \mathrm{Na}$ & 593.0668 & 593.0657 & +1.94 \\
{$[\mathrm{M}+\mathrm{Na}-44-18]^{+}$} & $\mathrm{C}_{25} \mathrm{H}_{26} \mathrm{O}_{6} \mathrm{~N}_{2} \mathrm{~V}_{2} \mathrm{Na}$ & 575.0562 & 575.0522 & +6.97 \\
{$[\mathrm{M}+\mathrm{Na}-98]^{+}$} & $\mathrm{C}_{20} \mathrm{H}_{18} \mathrm{O}_{8} \mathrm{~N}_{2} \mathrm{~V}_{2} \mathrm{Na}$ & 538.9835 & 538.9837 & -0.39 \\
{$[\mathrm{M}+\mathrm{Na}-44-68]^{+}$} & $\mathrm{C}_{20} \mathrm{H}_{20} \mathrm{O}_{7} \mathrm{~N}_{2} \mathrm{~V}_{2} \mathrm{Na}$ & 525.0042 & 525.0058 & -3.06 \\
{$[\mathrm{M}+\mathrm{Na}-44-18-68]^{+}$} & $\mathrm{C}_{20} \mathrm{H}_{18} \mathrm{O}_{6} \mathrm{~N}_{2} \mathrm{~V}_{2} \mathrm{Na}$ & 506.9936 & 506.9936 & +0.01 \\
{$[\mathrm{M}+\mathrm{Na}-44-95]^{+}$} & $\mathrm{C}_{19} \mathrm{H}_{19} \mathrm{O}_{7} \mathrm{NV}_{2} \mathrm{Na}$ & 497.9933 & 497.9911 & +4.50 \\
\hline
\end{tabular}

(Figure 3b). All observed ions from $\mathrm{m} / \mathrm{z} 637$ were even-electron ions (Table 2). Compared with the fragmentation of $m / z 614$, the fragmentation patterns of $\mathrm{m} / \mathrm{z} 637$ were simple. For example, the losses of 68 , 69 , and $70 \mathrm{Da}$ occurred during the fragmentation of $\mathrm{m} / \mathrm{z} 614$, but only the loss of 68 Da occurred for $\mathrm{m} / \mathrm{z}$ 637 (Table 2).

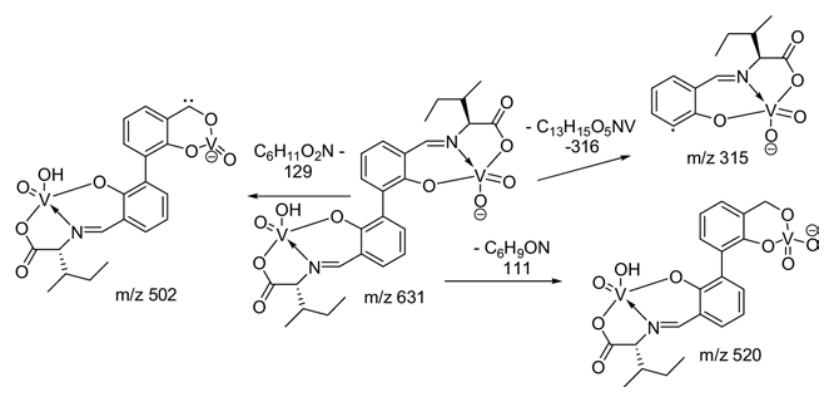

Scheme 3. Major fragmentation pathways of the hydrolysis product of oxovanadium Complex 1.
In the MS spectrum of the hydrolysis product of Complex 1, three major peaks that possibly correspond to $\left[\mathrm{M}+\mathrm{H}_{2} \mathrm{O}-\mathrm{H}\right]^{-}$at $m / z$ 631, $\left[\mathrm{M}+\mathrm{H}_{2} \mathrm{O}-2 \mathrm{H}+\mathrm{Na}\right]^{-}$at $m / z 653$, and $\left[\mathrm{M}+\mathrm{H}_{2} \mathrm{O}-2 \mathrm{H}+\mathrm{K}\right]^{-}$at $m / z 669$ were observed, in addition to the ion at $\mathrm{m} / \mathrm{z} 614$ (Figure 2c). The relatively simple MS/MS spectrum of the precursor ion $\left[\mathrm{M}+\mathrm{H}_{2} \mathrm{O}-\mathrm{H}\right]^{-}$at $\mathrm{m} / \mathrm{z} 631$ indicated the even-

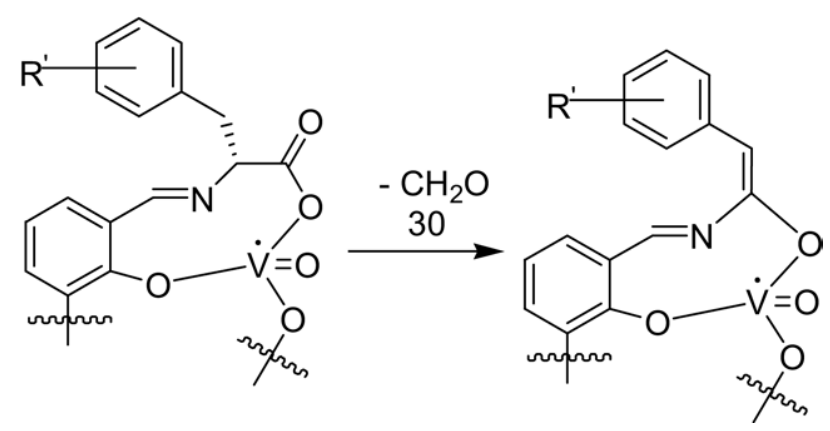

Scheme 4. Loss of the $\mathrm{CH}_{2} \mathrm{O}$ molecule when $\mathrm{R}$ includes phenyl. 
Table 3. Major fragment ions from oxovanadium complex 2 in negative-ion mode and their elemental constituents (collision energy at $35 \mathrm{eV})$

\begin{tabular}{|c|c|c|c|c|}
\hline Fragment ions & Formula & Calculated & Observed & Error (ppm) \\
\hline$[\mathrm{M}]^{--}$ & $\mathrm{C}_{34} \mathrm{H}_{28} \mathrm{O}_{11} \mathrm{~N}_{2} \mathrm{~V}_{2}$ & 742.0578 & 742.0583 & -0.69 \\
\hline$[\mathrm{M}-30]^{--}$ & $\mathrm{C}_{33} \mathrm{H}_{26} \mathrm{O}_{10} \mathrm{~N}_{2} \mathrm{~V}_{2}$ & 712.0472 & 712.0471 & +0.21 \\
\hline$[\mathrm{M}-44]^{--}$ & $\mathrm{C}_{33} \mathrm{H}_{28} \mathrm{O}_{9} \mathrm{~N}_{2} \mathrm{~V}_{2}$ & 698.0680 & 698.0686 & -0.85 \\
\hline$[\mathrm{M}-44-18]^{--}$ & $\mathrm{C}_{33} \mathrm{H}_{26} \mathrm{O}_{8} \mathrm{~N}_{2} \mathrm{~V}_{2}$ & 680.0574 & 680.0577 & -0.42 \\
\hline$[\mathrm{M}-44-30]^{--}$ & $\mathrm{C}_{32} \mathrm{H}_{26} \mathrm{O}_{8} \mathrm{~N}_{2} \mathrm{~V}_{2}$ & 668.0574 & 668.0572 & +0.27 \\
\hline$\left[^{M}-44-44\right]^{--}$ & $\mathrm{C}_{32} \mathrm{H}_{28} \mathrm{O}_{7} \mathrm{~N}_{2} \mathrm{~V}_{2}$ & 654.0781 & 654.0761 & +3.13 \\
\hline$[\mathrm{M}-44-44-18]^{--}$ & $\mathrm{C}_{32} \mathrm{H}_{26} \mathrm{O}_{6} \mathrm{~N}_{2} \mathrm{~V}_{2}$ & 636.0676 & 636.0686 & -1.63 \\
\hline$[\mathrm{M}-44-134]^{-}$ & $\mathrm{C}_{24} \mathrm{H}_{18} \mathrm{O}_{8} \mathrm{~N}_{2} \mathrm{~V}_{2}$ & 564.9948 & 564.9965 & -2.94 \\
\hline [M-44-18-121] $^{-}$ & $\mathrm{C}_{25} \mathrm{H}_{17} \mathrm{O}_{7} \mathrm{~N}_{2} \mathrm{~V}_{2}$ & 558.9921 & 558.9920 & +0.15 \\
\hline [M-44-147] $^{--}$ & $\mathrm{C}_{24} \mathrm{H}_{19} \mathrm{O}_{8} \mathrm{NV}_{2}$ & 550.9995 & 551.0007 & -2.05 \\
\hline [M-44-18-132] $]^{--}$ & $\mathrm{C}_{24} \mathrm{H}_{18} \mathrm{O}_{7} \mathrm{~N}_{2} \mathrm{~V}_{2}$ & 547.9999 & 547.9995 & +0.72 \\
\hline$[\mathrm{M}-44-159]^{--}$ & $\mathrm{C}_{23} \mathrm{H}_{19} \mathrm{O}_{8} \mathrm{NV}_{2}$ & 538.9995 & 539.0024 & -5.29 \\
\hline$[\mathrm{M}-44-44-134]^{--}$ & $\mathrm{C}_{23} \mathrm{H}_{18} \mathrm{O}_{6} \mathrm{~N}_{2} \mathrm{~V}_{2}$ & 520.0050 & 520.0014 & +6.80 \\
\hline${ }^{[M-44-44-147]^{--}}$ & $\mathrm{C}_{23} \mathrm{H}_{19} \mathrm{O}_{6} \mathrm{NV}_{2}$ & 507.0097 & 507.0059 & +7.56 \\
\hline$\left[^{\mathrm{M}-44-44-18-134]^{--}}\right.$ & $\mathrm{C}_{23} \mathrm{H}_{15} \mathrm{O}_{5} \mathrm{~N}_{2} \mathrm{~V}_{2}$ & 501.9944 & 501.9955 & -2.16 \\
\hline [M-44-44-18-147] $^{--}$ & $\mathrm{C}_{23} \mathrm{H}_{17} \mathrm{O}_{5} \mathrm{NV}_{2}$ & 488.9991 & 488.9965 & +5.45 \\
\hline$\left[\mathrm{V}_{2} \mathrm{O}_{7}\right]^{--}$ & $\mathrm{V}_{2} \mathrm{O}_{7}$ & 213.8529 & 213.8541 & -5.59 \\
\hline$\left[\mathrm{C}_{3} \mathrm{NV}_{2} \mathrm{O}_{3}\right]^{-}$ & $\mathrm{C}_{3} \mathrm{NV}_{2} \mathrm{O}_{3}$ & 199.8763 & 199.8773 & -5.03 \\
\hline$\left[\mathrm{V}_{2} \mathrm{O}_{5}\right]^{--}$ & $\mathrm{V}_{2} \mathrm{O}_{5}$ & 181.8630 & 181.8635 & -2.31 \\
\hline
\end{tabular}

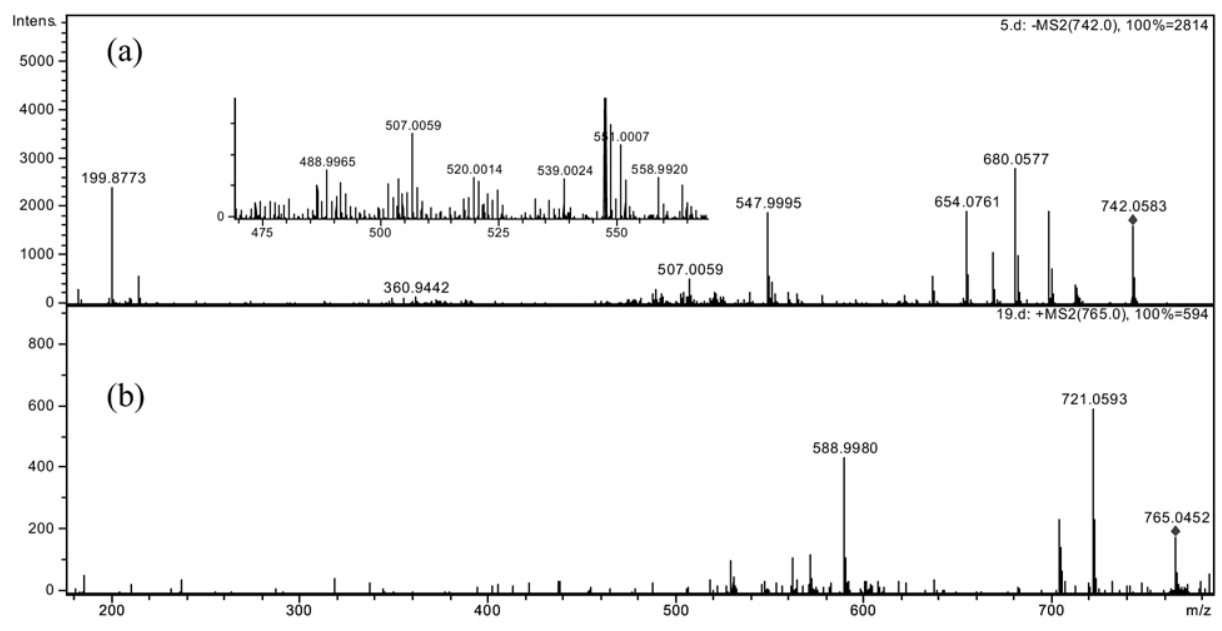

Figure 4. MS/MS spectra of oxovanadium Complex 2: (a) selected [M] ${ }^{--}$at $m / z 742$ (collision energy at $35 \mathrm{eV})$, and (b) selected $[\mathrm{M}+\mathrm{Na}]^{+}$at $\mathrm{m} / \mathrm{z} 765$ (collision energy at $\left.30 \mathrm{eV}\right)$.

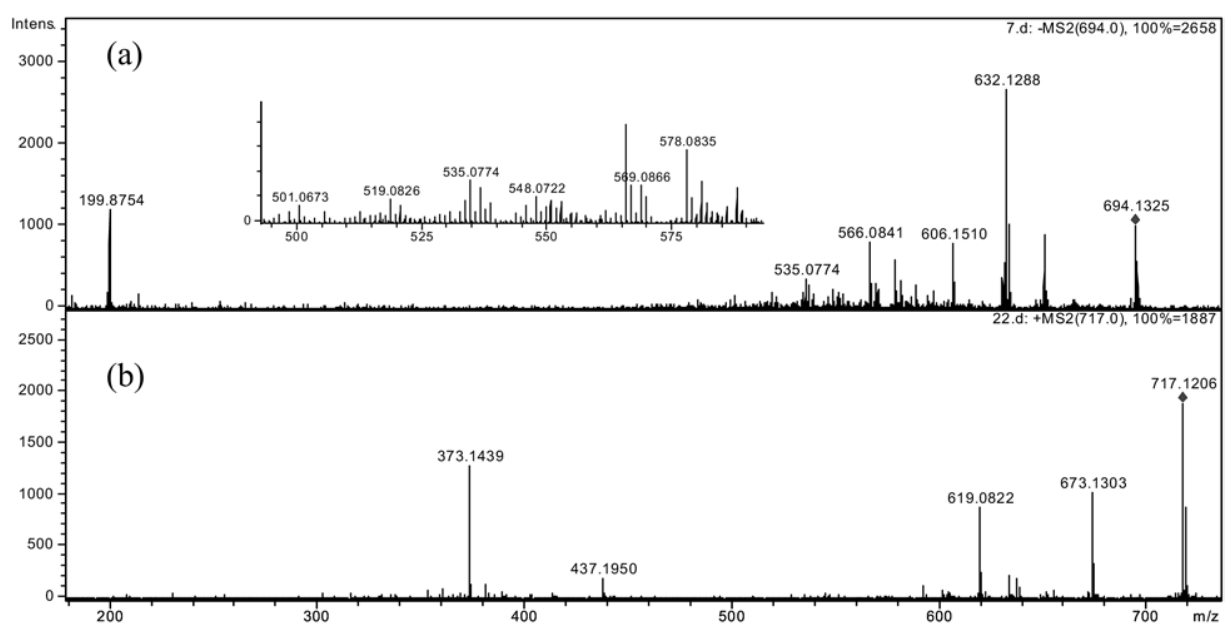

Figure 5. MS/MS spectra of oxovanadium Complex 3: (a) selected [M] $]^{--}$at $m / z 694$ (collision energy at $39 \mathrm{eV}$ ), and (b) selected $[\mathrm{M}+\mathrm{Na}]^{+}$at $\mathrm{m} / \mathrm{z} 717$ (collision energy at $25 \mathrm{eV}$ ). 
Table 4. Major fragment ions from oxovanadium complex 3 in negative-ion mode and their elemental constituents (collision energy at $39 \mathrm{eV}$ )

\begin{tabular}{|c|c|c|c|c|}
\hline Fragment ions & Formula & Calculated & Observed & Error (ppm) \\
\hline$\overline{[\mathrm{M}]^{--}}$ & $\mathrm{C}_{32} \mathrm{H}_{36} \mathrm{O}_{9} \mathrm{~N}_{2} \mathrm{~V}_{2}$ & 694.1306 & 694.1325 & -2.78 \\
\hline$[\mathrm{M}-44]^{--}$ & $\mathrm{C}_{31} \mathrm{H}_{36} \mathrm{O}_{7} \mathrm{~N}_{2} \mathrm{~V}_{2}$ & 650.1407 & 650.1402 & +0.87 \\
\hline$[\mathrm{M}-44-18]^{--}$ & $\mathrm{C}_{31} \mathrm{H}_{34} \mathrm{O}_{6} \mathrm{~N}_{2} \mathrm{~V}_{2}$ & 632.1302 & 632.1288 & +2.13 \\
\hline$[\mathrm{M}-44-44]^{--}$ & $\mathrm{C}_{30} \mathrm{H}_{36} \mathrm{O}_{5} \mathrm{~N}_{2} \mathrm{~V}_{2}$ & 606.1509 & 606.1510 & -0.11 \\
\hline$[M-44-56]^{--}$ & $\mathrm{C}_{27} \mathrm{H}_{28} \mathrm{O}_{7} \mathrm{~N}_{2} \mathrm{~V}_{2}$ & 594.0781 & 594.0843 & -10.3 \\
\hline$[\mathrm{M}-44-44-18]^{--}$ & $\mathrm{C}_{30} \mathrm{H}_{34} \mathrm{O}_{4} \mathrm{~N}_{2} \mathrm{~V}_{2}$ & 588.1403 & 588.1417 & -2.29 \\
\hline$[\mathrm{M}-44-69]^{--}$ & $\mathrm{C}_{27} \mathrm{H}_{29} \mathrm{O}_{7} \mathrm{NV}_{2}$ & 581.0829 & 581.0810 & +3.32 \\
\hline$[\mathrm{M}-44-18-54]^{--}$ & $\mathrm{C}_{27} \mathrm{H}_{28} \mathrm{O}_{6} \mathrm{~N}_{2} \mathrm{~V}_{2}$ & 578.0832 & 578.0835 & -0.48 \\
\hline$[\mathrm{M}-44-81]^{--}$ & $\mathrm{C}_{26} \mathrm{H}_{29} \mathrm{O}_{7} \mathrm{NV}_{2}$ & 569.0829 & 569.0866 & -6.50 \\
\hline$[\mathrm{M}-44-84]^{--}$ & $\mathrm{C}_{26} \mathrm{H}_{28} \mathrm{O}_{6} \mathrm{~N}_{2} \mathrm{~V}_{2}$ & 566.0832 & 566.0841 & -1.53 \\
\hline [M-44-44-55] $^{-}$ & $\mathrm{C}_{25} \mathrm{H}_{25} \mathrm{O}_{6} \mathrm{~N}_{2} \mathrm{~V}_{2}$ & 551.0597 & 551.0562 & +6.40 \\
\hline$[\mathrm{M}-44-84]^{--}$ & $\mathrm{C}_{26} \mathrm{H}_{26} \mathrm{O}_{5} \mathrm{~N}_{2} \mathrm{~V}_{2}$ & 548.0726 & 548.0722 & +0.87 \\
\hline$[\mathrm{M}-44-44-69]^{--}$ & $\mathrm{C}_{26} \mathrm{H}_{29} \mathrm{O}_{5} \mathrm{NV}_{2}$ & 537.0930 & 537.0912 & +3.47 \\
\hline$[\mathrm{M}-44-44-71]^{--}$ & $\mathrm{C}_{26} \mathrm{H}_{27} \mathrm{O}_{5} \mathrm{NV}_{2}$ & 535.0774 & 535.0774 & +0.06 \\
\hline$[\mathrm{M}-44-44-18-69]^{--}$ & $\mathrm{C}_{26} \mathrm{H}_{27} \mathrm{O}_{4} \mathrm{NV}_{2}$ & 519.0825 & 519.0826 & -0.21 \\
\hline$\left[\mathrm{V}_{2} \mathrm{O}_{7}\right]^{--}$ & $\mathrm{V}_{2} \mathrm{O}_{7}$ & 213.8529 & 213.8539 & -4.78 \\
\hline$\left[\mathrm{C}_{3} \mathrm{NV}_{2} \mathrm{O}_{3}\right]^{-}$ & $\mathrm{C}_{3} \mathrm{NV}_{2} \mathrm{O}_{3}$ & 199.8763 & 199.8754 & +4.47 \\
\hline$\left[\mathrm{V}_{2} \mathrm{O}_{5}\right]^{--}$ & $\mathrm{V}_{2} \mathrm{O}_{5}$ & 181.8630 & 181.8627 & +2.05 \\
\hline
\end{tabular}

electron ion character of $m / z 631$ (Figure 3c). The product ion at $\mathrm{m} / \mathrm{z} 315$ and the lack of low-mass characteristic ions indicated the cleavage of the $\mathrm{V}-\mathrm{O}-\mathrm{V}$ bridge bond due to hydrolysis (Scheme 3).

\section{MS and MS/MS of Complexes 2-6}

For Complex 2, the radical molecular anion [M] ${ }^{-}$at $m / z$ 742 and the positive adduct ions of $[\mathrm{M}+\mathrm{H}]^{+}$at $m / z 743$, $[\mathrm{M}+\mathrm{Na}]^{+}$at $m / z 765$, and $[\mathrm{M}+\mathrm{K}]^{+}$at $m / z 781$ were observed. As well as Complex 1, the relative intensity of the sodium adduct is the highest in positive-ion mode (Supporting Information, which can be found in the electronic version of this article). The fragmentation pattern of the precursor ions $\left[\mathrm{M}^{--}\right.$at $m / z 742$ was very similar to that of $\mathrm{m} / \mathrm{z} 614$ in Complex 1. A series of low-abundance peaks similar to the EI spectrum and low-mass characteristic ions at $m / z 214,200$, and 184 were observed in the MS/MS spectrum of $\mathrm{m} / \mathrm{z} 742$ (Figure $4 \mathrm{a}$ ). The only fragmentation difference between $\mathrm{m} / \mathrm{z} 742$ in Complex 2 and $\mathrm{m} / \mathrm{z} 614$ in Complex $\mathbf{1}$ was the obvious loss of a $\mathrm{CH}_{2} \mathrm{O}$ molecule from $\mathrm{m} / \mathrm{z}$ 742. A possible reason for this difference is that the doublebond formed by the loss of a $\mathrm{CH}_{2} \mathrm{O}$ molecule is stabilized by phenyl during the fragmentation of $m / z 742$ in Complex 2 (Scheme 4). The fragmentation patterns of Complexes 3-6 in negative-ion mode supported this hypothesis; i.e., when $\mathrm{R}$ included phenyl, the loss of the $\mathrm{CH}_{2} \mathrm{O}$ molecule was obvious. As expected, the fragmentation patterns of $[\mathrm{M}+\mathrm{Na}]^{+}$at $m / z 765$ was simple compared with that of $m / z 742$ (Figure 4).

In summary, in positive- or negative-ion mode (particularly in negative-ion mode), the fragment mechanisms of Complexes 2-6 were in accordance with that of Complex 1. Spectra are shown in Figures 4 and 5 and Supporting Information. The exact masses of major product ions are listed in Tables 3 and 4 and Supporting Information.

\section{Conclusions}

The information obtained from respective fragmentation experiments will be especially valuable for the rapid identification of bimetallic oxovanadium complexes, which are very difficult to purify. The finding of stable radical molecular ions $[\mathrm{M}]^{-}$might provide a series of type complexes for studying the character of radical. The behavior of the radical in the gas phase during the CID MS/MS experiments is of scientific interest. Combined information from the fragmentation of radical molecular ion $[\mathrm{M}]^{--}$and the corresponding hydrolysis product contributes to the understanding of the structure and character of bimetallic oxovanadium complexes and might facilitate the design of new bimetallic oxovanadium catalysts. Further studies in this field are being carried out in our laboratory.

\section{Acknowledgments}

The authors thank Professor Liuzhu Gong of the University of Science and Technology of China and Dr. Qixiang Guo of Chengdu Institute of Organic Chemistry for providing the samples of bimetallic oxovanadium complexes.

\section{References}

1. Thompson, K. H.; McNeill, J. H.; Orvig, C. Vanadium Compounds as Insulin Mimics. Chem. Rev. 1999, 99, 2561-2571.

2. Cohen, N.; Halberstam, M.; Shlimovich, P.; Chang, C. J.; Shamoon, H.; Rossetti, L. Oral Vanadyl Sulfate Improves Hepatic and Peripheral Insulin Sensitivity in Patients with Non-Insulin-Dependent Diabetes Mellitus. J. Clin. Invest. 1995, 95, 2501-2509.

3. Boden, G.; Chen, X.; Ruiz, J.; Rossum, G. D. V.; Turco, S. Effects of Vanadyl Sulfate on Carbohydrate and Lipid Metabolism in Patients with Non-Insulin-Dependent Diabetes mellitus. Metabolism 1996, 45, $1130-1135$.

4. Goldfine, A. B.; Patti, M.-E.; Zuberi, L.; Goldstein, B. J.; LeBlanc, R.; Landaker, E. J.; Jiang, Z. Y.; Willsky, G. R.; Kahn, C. R. Metabolic Effects of Vanadyl Sulfate in Humans with Non-Insulin-Dependent Diabetes mellitus: In Vivo and In Vitro Studies. Metabolism 2000, 49, 400-410.

5. Cusi, K.; Cukier, S.; De Fronzo, R. A.; Torres, M.; Puchulu, F. M.; Redondo, J. C. Vanadyl Sulfate Improves Hepatic and Muscle Insulin 
Sensitivity in Type 2 Diabetes. J. Clin. Endocrinol. Metab. 2001, 86, 1410-1417.

6. Butler, A.; Clague, M. J.; Meister, G. E. Vanadium Peroxide Complexes. Chem. Rev. 1994, 94, 625-638.

7. Crans, D. C.; Chen, H. J.; Felty, R. A. Synthesis and Reactivity of Oxovanadium(V) Trialkoxides of Bulky and Chiral Alcohols. J. Am. Chem. Soc. 1992, 114, 4543-4550.

8. Maeda, Y.; Kakiuchi, N.; Matsumura, S.; Nishimura, T.; Kawamura, T.; Uemura, S. Oxovanadium Complex-Catalyzed Aerobic Oxidation of Propargylic Alcohols. J. Org. Chem. 2002, 67, 6718-6724.

9. Santoni, G.; Licini, G.; Rehder, D. Catalysis of Oxo Transfer to Prochiral Sulfides by Oxovanadium(V) Compounds that Model the Active Center of Haloperoxidases. Chem. Eur. J. 2003, 9, 4700-4708.

10. Feyel, S.; Dobler, J.; Schröder, D.; Sauer, J.; Schwarz, H. Thermal Activation of Methane by Tetranuclear [V4O10]+. Angew. Chem. Int. Ed. 2006, 45, 4681-4685.

11. Chu, C. Y.; Hwang, D. R.; Wang, S. K.; Uang, B. J. Chiral Oxovanadium Complex Catalyzed Enantioselective Oxidative Coupling of 2-Naphthols. Chem. Commun. 2001, 980-981.

12. Hon, S. W.; Li, C. H.; Kuo, J. H.; Barhate, N. B.; Liu, Y. H.; Wang, Y.; Chen, C. T. Catalytic Asymmetric Coupling of 2-Naphthols by Chiral Tridentate Oxovanadium(IV) Complexes. Org. Lett. 2001, 3, 869-872.

13. Barhatre, N. B.; Chen, C. T. Catalytic Asymmetric Oxidative Couplings of 2-Naphthols by Tridentate N-Ketopinidene-Based Vanadyl Dicarboxylates. Org. Lett. 2002, 4, 2529-2532.

14. Tada, M.; Taniike, T.; Kantam, L. M.; Iwasawa, Y. Chiral Self-Dimerization of Vanadium Complexes on $\mathrm{A} \mathrm{SiO}_{2}$ Surface: The First Heterogeneous Catalyst for Asymmetric 2-naphthol Coupling. Chem. Commun. 2004, 2542-2543.

15. Luo, Z. B.; Liu, Q. Z.; Gong, L. Z.; Cui, X.; Mi, A. Q.; Jiang, Y. Z. The Rational Design of Novel Chiral Oxovanadium(IV) Complexes for Highly Enantioselective Oxidative Coupling of 2-Naphthols. Chem. Commun. 2002, 914-915.

16. Luo, Z. B.; Liu, Q. Z.; Gong, L. Z.; Cui, X.; Mi, A. Q.; Jiang, Y. Z. Novel Achiral Biphenol-Derived Diastereomeric Oxovanadium(IV) Com- plexes for Highly Enantioselective Oxidative Coupling of 2-Naphthols. Angew. Chem. Int. Ed. 2002, 41, 4532-4535.

17. Guo, Q. X.; Wu, Z. J.; Luo, Z. B.; Liu, Q. Z.; Ye, J. L.; Luo, S. W.; Cun L. F.; Gong, L. Z. Highly Enantioselective Oxidative Couplings of 2-Naphthols Catalyzed by Chiral Bimetallic Oxovanadium Complexes with Either Oxygen or Air as Oxidant. J. Am. Chem. Soc. 2007, 129, 13927-13938.

18. Somei, H.; Asano, Y.; Yoshida, T.; Takizawa, S.; Yamataka, H.; Sasai, H. Dual Activation in a Homolytic Coupling Reaction Promoted by an Enantioselective Dinuclear Vanadium(IV) Catalyst. Tetrahedron Lett. 2004, 45, 1841-1844.

19. Bortolini, O.; Conte, V.; Furia, F. D.; Moro, S. Direct Evidence of Solvent-Peroxovanadium Clusters by Electrospray Ionization Mass Spectrometry. Eur. J. Inorg. Chem. 1998, 1193-1197.

20. Bortolini, O.; Carraro, M.; Conte, V.; Moro, S. Histidine-Containing Bisperoxovanadium(V) Compounds: Insight into the Solution Structure by an ESI-MS and 51V-NMR Comparative Study. Eur. J. Inorg. Chem. 1999, 1489-1495.

21. Bonchio, M.; Bortolini, O.; Conte, V.; Moro, S. Characterization and Reactivity of Triperoxovanadium Complexes in Protic Solvents. Eur. J. Inorg. Chem. 2001, 2913-2919.

22. Bortolini, O.; Carraro, M.; Conte, V.; Moro, S. Vanadium-Bromoperoxidase-Mimicking Systems: Direct Evidence of a Hypobromite-Like Vanadium Intermediate. Eur. J. Inorg. Chem. 2003, 42-46.

23. Kaczorowska, M.; Schröder, D.; Schwarz, H. Fragmentation of Alkoxo(Catecholato)Vanadium(V) Complexes [(C6H4O2)V(OR1)(OR2)]+ in the Gas Phase. Eur. J. Inorg. Chem. 2005, 2919-2923.

24. Feyel, S.; Schröder, D.; Schwarz, H. Gas-Phase Oxidation of Isomeric Butenes and Small Alkanes by Vanadium-Oxide and -Hydroxide Cluster Cations. J. Phys. Chem. A 2006, 110, 2647-2654.

25. Zeng, Q. L.; Chen, W. Z.; Zhao, Y. F. Electrospray Ionization Mass Spectral Fragmentation Study of Amino Acid Derived Oxovanadium Schiff Base Complexes and (Oxo)-Peroxovanadium Schiff Base Complexes. Int. J. Mass Spectrom. 2007, 262, 161-167. 